\title{
MAKING LOCAL PRODUCT ATTRACTIVE: THE ROLE OF INDIGENOUS VALUE IN IMPROVING MARKET PERFORMANCE
}

\author{
Harini Abrilia SETYAWATI \\ Jenderal Soedirman University, Faculty of Economics and Business, \\ Indonesia, e-mail: harini.abrilia.setyawati@gmail.com \\ Agus SUROSO \\ Jenderal Soedirman University, Faculty of Economics and Business, \\ Indonesia, e-mail: roso.fe2014@gmail.com \\ Pramono Hari ADI \\ Jenderal Soedirman University, Faculty of Economics and Business, \\ Indonesia, e-mail: hariadipramono@gmail.com \\ Wiwiek Robiatul ADAWIYAH* \\ Jenderal Soedirman University, Faculty of Economics and Business, \\ Indonesia, e-mail: wiwiek.ra@gmail.com

\section{Irfan HELMY} \\ Putra Bangsa Economic College, Faculty of Economics and Business, \\ Indonesia, e-mail: risetirfan@gmail.com
}

Citation: Setyawati H.A., Suroso A., Adi, P.H., Adawiyah, W.R. \& Helmy, I. (2020). MAKING LOCAL PRODUCT ATTRACTIVE: THE ROLE OF INDIGENOUS VALUE IN IMPROVING MARKET PERFORMANCE. GeoJournal of Tourism and Geosites, 29(2), 746-755. https://doi.org/10.30892/gtg.29228-503

\begin{abstract}
This study scrutinizes the overlooked role of indigenous value as the prime constituent of product attractiveness and demonstrate how the indigenous products' value adds to its market performance in the highly dynamic work environment. Data was collected by a mean of questionaires which was distributed to 176 Small and Medium Enterprises producing indigenous products. The tool of analysis used was partial least square (PLS). The findings showed that indigenous product attractiveness mediates the relationship between market sensing capability and marketing performance. Nonetheless, the relationship between innovative capability and product attractiveness was not supported.
\end{abstract}

Key words: market sensing capability, innovation capability, indigenous product attractiveness, and marketing performance

\footnotetext{
* Corresponding author
} 


\section{INTRODUCTION}

The tourism market plays a crucial role in both developed and developing countries (Sigala, 2018). Identifying, promoting, and integrating natural, original and traditional heritage in tourism development planning is essential (Ilieș et al., 2010). The purchase of souvenirs is one of tourism spending, as a sign of functional interaction between tourists and the host country (Sims, 2009). Past studies indicated that the purchase of souvenirs represents $80 \%$ of tourism spending (Dagooc, 2010), with estimated annual revenue of $\$ 17$ billion (www.hoovers.com). A country that relies on the tourism industry makes more than $\$ 30$ million a year from selling souvenirs alone. It is apparent that local products play a fundamental role in fostering economic development, especially in developing countries (Chambers et al., 2007). Therefore, indigenous product has received tremendous attention among scholars worldwide.

However, some studies revealed a deficiency of interest in indigenous products in emerging market economies. The domestic consumers place higher preferences on imported goods while perceiving local products as possessing lower quality and less attractive (Ayob \& Hussain, 2016; Dyah \& Korry, 2017). Therefore, small businesses (SME) indulging in local products face challenging tasks on how to gain local and international customers' attention through product attractiveness.

Previous researchers have explored factor related to product attractiveness, such as adding features (Angelis et al., 2009), consumer's need adaptability, unfamiliar product (Schnurr et al., 2017), and product innovation (Pono et al., 2019). Meanwhile, in today's rapid business change, making the product attractive is more challenging tasks because consumers are more demanding than ever. They are not only expecting a reasonable price with good quality products but looking for more emotional values. The product connected with indigenous cultures could produce more emotional value to consumers (Chen et al., 2017). However, to our knowledge, there was a little body of research that focused on this issue. Addressing this gap, this study empirically examined the new concept of indigenous product attractiveness on improving SMEs' market performance.

The term of indigenous product is an artifact designed and used by a particular community of people such as tools, clothing, crafts, and goods (Dormer, 1997). Indigenous product is an invented artifact that produces by humans or the community of people whose goals were to fulfill their needs for everyday life. It typically represents the regional identity where the artifacts were created. It is the root of the new invention for future products (Shaari, 2015). The indigenous product creates emotional value, which may engage customer attractiveness. Indigenous product attractiveness consists of three distinguished indicators, and there are indigenous style, indigenous motive, and indigenous design (Setyawati, 2018). Indigenous value could improve product attractiveness trough cultural connections between the product and people.

So, indigenous product attractiveness can become one of the critical differentiation strategies in today's competitive marketplace. In the present study, we suggest that indigenous product attractiveness may be an important mediating mechanism that explains how market sensing and innovation capability on market performance. However, only a few studies focused on market sensing and innovation capability in the SME context (Wardani \& Widodo, 2020).

Since SMEs tend to have intense personal contact with their customers (Coviello et al., 2000), the market sensing capability and innovation capability become the fundamental factors for SMEs that lead to better performance (Verreneey et al., 2019).

Indonesia is an emerging country that provides many distinctive cultures. Consequently, the growth of local products increasing rapidly. Regarding this issue, the 
Indonesian government promotes "one village one product" (OVOP) program to improve the competitive advantage of local products. The primary goal of OVOP is to encourages the use of local resources (e.g., nature, people, and technology), rely on the indigenous value of the local community in order to make the product more attractive.

Finally, this research has several contributions. First, this is the premier research that revealed the importance of indigenous product attractiveness - as the integrating of indigenous value and product attractiveness- on SMEs' market performance. Second, this study investigated the extent to which market sensing capability and innovation capability related to market performance with indigenous product attractiveness as a mediating variable. Based on the resource-based view theory, we proposed a new theoretical model of product attractiveness from the marketing perspective. This study also provides implications and suggestions for future research.

\section{MATERIALS AND METHODS}

\section{Market Sensing Capability and Marketing Performance}

Marketing performance is part of organizational performance. Marketing performance is a measure of the performance of activities throughout a company's marketing process. Also, marketing performance can be viewed as a concept used to measure the extent to which market success can be achieved with a product manufactured by the company. Day (1994) emphasizes the need to design the market sensor as an organizational learning ability to drive strategic marketing, knowing customers, competitors and channel members to respond to market events and trends. Huber (1991) describes Market Sense as a company's ability to acquire and disseminate knowledge and use market intelligence when needed for organizational change.

In Day (1994; 2002), Market Sensing can be divided into three sub-processes: (i) sensing, (ii) sensory production and (iii) response. In a nutshell, meaning refers to the acquisition of information about consumers, competitors and other channel members, while meaning refers to the interpretation of information gathered from past experiences and knowledge. The answers relate to the use of information collected and interpreted during decision making. In other words, through unacknowledged reactions, information and knowledge become visible marketing actions.

Day (2002) stresses that the process of entering the market in market-oriented companies is more systematic, prudent and proactive than in other companies where this process is more ad hoc, reactive, limited and diffuse. Day (2002) organizations that dominate market recognition activities achieve competitive advantage and superior business performance. In other words, a company's ability to learn about its market environment and accurately use this information to guide its actions is a key factor in business performance (Vorhies \& Morgan, 2005). The market sensing capability is important in developing market focus to enhance the organizational performance (Bouguerra, 2020; Ahmed et al., 2017; Ardyan, 2016; Foley, 2004; Lindblom et al, 2008).

H1: market sensing capability influences positively on Indigenous product attractiveness

H3: market sensing capability influences positively on marketing performance

\section{Innovation Capability and Marketing Performance}

Product innovation has been widely studied in the field of marketing. Product innovation is considered a key driver for success in the market through a series of key initiatives. The initiative is the ability and success to be the first in marketing new products and new services, capabilities, and success that are considered very important by 
the customer, ability and success in introducing more innovative products and services, capabilities and success to bring faster new products and services to the market (Akgün et al., 2014; Avlonitis \& Salavou, 2007; Banerjee, 2002). Product innovation is the key to organizational renewal and success (Slater et al., 2013). Product innovation is goods, services, and ideas that are perceived as something new and different from goods, services, and ideas that have been there before (Solomon \& Stuart, 1997).

This innovation is an attempt by the company to prevent market saturation as well as by increasing the attractiveness of products with innovation. Companies certainly want their products to be different from competitors. Innovations are made based on differences not shared by competitors (Bharadwaj et al., 1993). Therefore, innovation can make the products offered by the company have high attractiveness. According to (Kartajaya, 2004), differentiation is all the efforts made by companies to create differences among competitors to provide the best value for consumers.

Innovation can only happen if the company has the ability to in novative (Laforet, 2011). Innovation capability has a role in improving marketing performance. In the perspective of RBV innovation capability is seen as a company's unique competence in adopting new products, new methods, solving problems through something new and speed in responding to change (Acquaah \& Agyapong, 2015; Lawson \& Samson, 2001).

According to Lawson and Samson (2001) innovation capability is a basic element in developing innovative output. According to the innovation of Adler and Shenbar (1990) innovation capability is defined as (1) the capacity to develop new products meet market needs; (2) the ability to apply appropriate process technologies to produce these new products; (3) the ability to develop and adopt new products and processes technologies to meet future needs; (4) and the ability to respond to accidental technological activities and unexpected opportunities created by competitors. Innovation capability leads organization to develop innovations continuously to respond the changing market environment (Slater et al., 2010) and its embedded with all the strategies, system and structure that support innovation in an organization (Gloet \& Samson, 2016). Previous research states that innovation shows that using traditional resources and capabilities to innovate can produce significant benefits for some industries (Presenzaet al., 2019). Innovation capability mediates the relationship between customer orientation and business performance (Huhtala et al., 2014).

H2: innovation capability influences positively on Indigenous product attractiveness H4: innovation capability influences positively on marketing performance

\section{Indigenous Product Attractiveness and Marketing Performance}

Cultural product representations play an important role in creating and reflecting the cultural identity of many cultures throughout the world. These cultural products are considered unique, so they have their charm. The results of previous studies show that the purchase intention of handmade products is higher when the product is used as a gift for close people. They do not consider the price, but rather look at the quality of the product (Fuchs et al., 2015). The attraction is a derivative of social cognitive theory in which the Social Cognitive Theory. Attractiveness is the capacity to cause interest and attract or gain the attention of another party. In a business context, this means that a provider or receiver can attract others' attention, resulting in increased loyalty and improved performance in the relationship (Kim et al., 2020). Baczyńska et al. (2018) revealed attractiveness level was showed by uniqueness, differentiation, interest and curiosity. Indigenous Product Attractiveness defined as product attributes reflected in local culture (Setyawati, 2018). Indicators of the Indigenous Product Attractiveness variables 
are indigenous motive attractiveness, indigenous style attractiveness, and indigenous symbol attractiveness. The addition of features to the product is known to be able to increase the attractiveness of the product, but this happens if the addition of these features is following the product (Angelis et al., 2009). Product attractiveness is recognized as a strategic factor to improve marketing performance; the attractiveness of the product must be maintained by incorporating several acculturative attributes (Ferdinand \& Fitriani, 2015). Formally, we hypothesize the following:

\section{$\mathrm{H}_{5}$ : Indigenous product attractiveness can increase marketing performance}

Based on the complete and in-depth literature, a research model can be developed as in Figure 1.

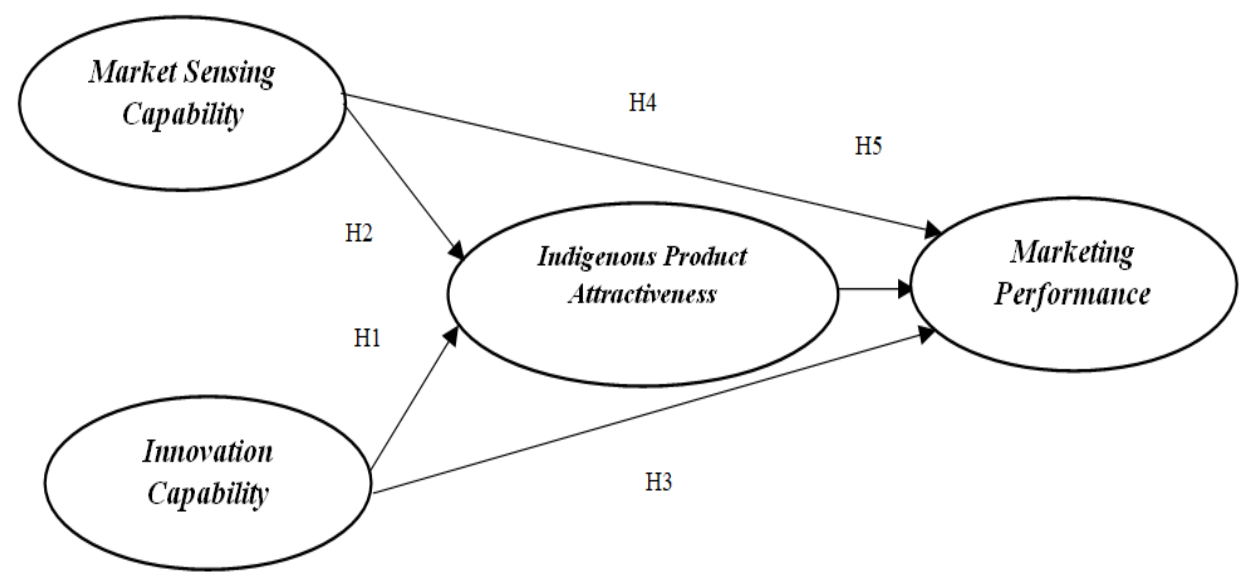

Figure 1. The conceptual model of relationship between market sensing capability and innovation capability to marketing performance through indigenous product attractiveness as a mediating variable

\section{METHODOLOGY}

This paper followed a cross-sectional quantitative study. The data was collected through questionnaires. In total, 14 items were used to examine the relationship between market sensing capability, innovation capability, indigenous product attractiveness, and marketing performance. The items used to measure Market sensing capability can be divided into three-item, learning about the environment, tracking competitor strategy, understanding the market trend, responsive. The items used to measure Innovation capability can be divided into three-item new product or service innovation, methods of production or rendering of services, risk-taking by key executives, Seeking unusual and novel solutions (Miller \& Friesen, 1983). Indigenous product attractiveness measure by indigenous motive attractiveness, indigenous style attractiveness, indigenous symbol attractiveness (Setyawati, 2018). Marketing performance measure by three-item, sales growth, consumer growth, sales volume (Song \& Parry, 1997). Both groups were measured using the ten-point scale ( $1=$ strongly disagree, $10=$ strongly agree). All of the survey items were translated from English into Indonesian language using a method of forwarding and backward translation (Brislin, 1970). Implementation of this method includes the following steps: forward translation, back-translation expert panel, pre-testing and cognitive interviewing, and final version. The population in this study was 176 SMEs from batik industry located in Central Java. The survey was carried out from January 1st to October 1st, 2019. Convinience sampling method were employed to distributed 176 questionnaires and 
only 100 questionnaires were adequately filled. Thus respond rate for the survey is $56,8 \%$. The study used PLS through the SmartPLS 3.0 software to test the hypothesis.

\section{RESULTS DISCUSSIONS}

Market sensing capability and innovation capability indicators are all valid with factor loading exceeds 0.7. Indigenous product attractiveness and marketing performance were assessed with three items indicators, and all indicators are considered valid since factors loading exceeds 0.7. As shown in Table 1 was the results of Measurement Model Evaluation Results.

Table 1. Measurement Model Evaluation Results

\begin{tabular}{|l|c|}
\hline \multicolumn{1}{|c|}{ Constructs / Indicators } & Factor Loading \\
\hline Market sensing capability, CR o,932; AVE 0,774 & \\
We are able to identify the environment, such as customers and markets. & 0,905 \\
We are able to identify competitors' strategies & 0,833 \\
We are able to identify new business trends & 0,911 \\
We are able to quickly capture the changes that occur & 0,869 \\
\hline Innovation capability, Miller \& Friesen (1983), CR 0,917; AVE 0,734 & \\
We are able to create new products or services & 0,829 \\
We are able to innovate in production methods or service delivery & 0,827 \\
We are able to take risks on decisions to innovate & 0,853 \\
We are able to find solutions through unusual methods or new solutions. & 0,915 \\
\hline Indigenous product attractiveness, CR o,851; AVE o,657 & 0,908 \\
We have interesting local specialties styles & 0,792 \\
We have interesting local specialties motives & 0,722 \\
We have interesting local specialties symbols & 0,952 \\
\hline Marketing performance, Song dan Parry (1997:3), CR 0,938; AVE o,835 & 0,862 \\
Our company's sales have increased. & 0,925 \\
Our company has a higher growth in the number of customers. & \\
Our company's sales growth has increased. &
\end{tabular}

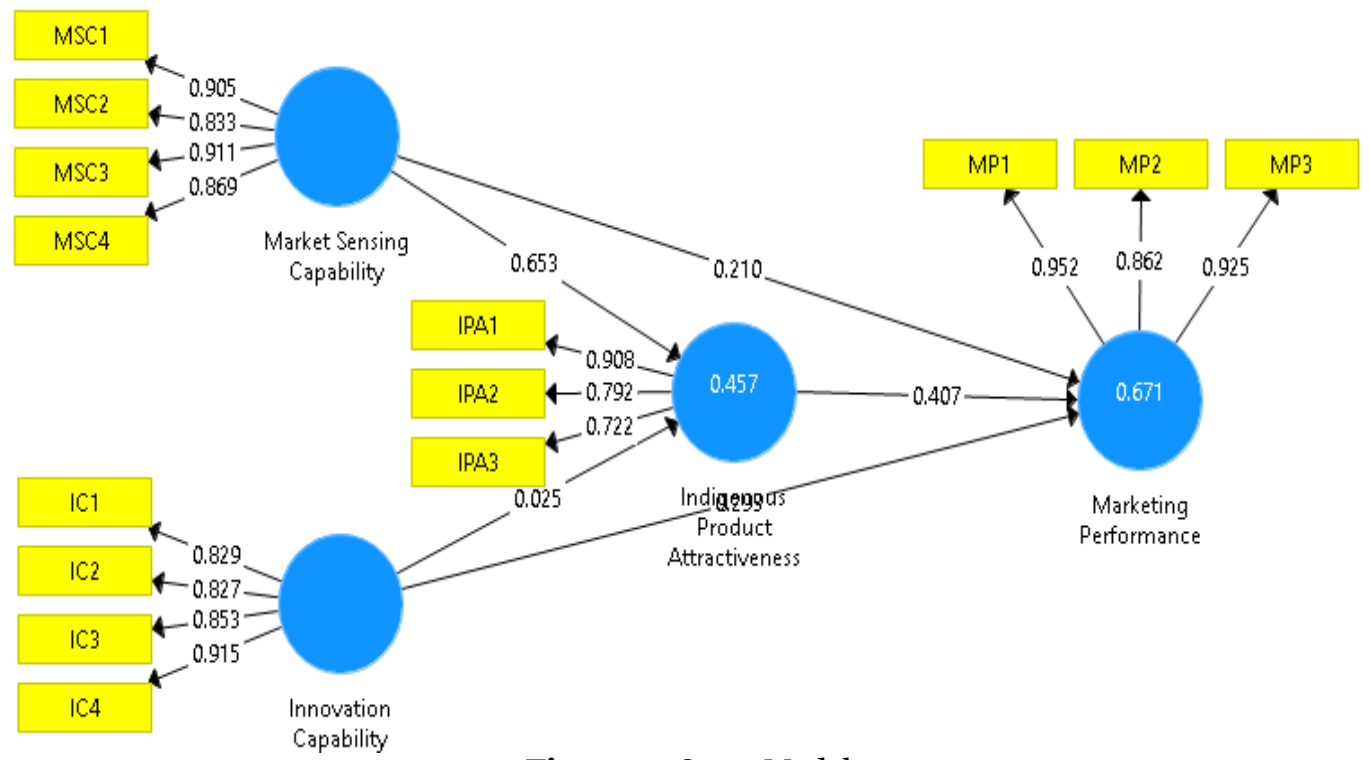

Figure 2. Outer Model 
Harini Abrilia SETYAWATI, Agus SUROSO,

Pramono Hari ADI, Wiwiek Robiatul ADAWIYAH, Irfan HELMY

Table 2. Inner Model Relationship Coefficient

\begin{tabular}{|l|c|c|c|}
\hline \multicolumn{1}{|c|}{ Relationship } & $\begin{array}{c}\text { Original Sample } \\
\text { estimate }\end{array}$ & $\begin{array}{c}\text { Standard } \\
\text { deviation }\end{array}$ & T-statistic \\
\hline $\begin{array}{l}\text { Market sensing capability } \rightarrow \text { Indigenous } \\
\text { product attractiveness }\end{array}$ & 0,653 & 0,206 & 3,169 \\
\hline $\begin{array}{l}\text { Innovation capability } \rightarrow \text { Indigenous product } \\
\text { attractiveness }\end{array}$ & 0,025 & 0,204 & 0,901 \\
\hline $\begin{array}{l}\text { Market sensing capability } \rightarrow \text { marketing } \\
\text { performance }\end{array}$ & 0,210 & 0,161 & 1,303 \\
\hline Innovation capability $\rightarrow$ marketing performance & 0,293 & 0,195 & 1,508 \\
\hline $\begin{array}{l}\text { Indigenous product attractiveness } \rightarrow \text { marketing } \\
\text { performance }\end{array}$ & 0,407 & 0,117 & 3,494 \\
\hline
\end{tabular}

Based on the result of the inner model analysis, as shown in Table 2, hypotheses 1 and 2 were supported. As expected Market sensing capability has a positive and significant influence ( $\mathrm{t}$-value 3,169 > t-table) on indigenous product attractiveness, and indigenous product attractiveness has a positive and significant influence ( $t$-value 3,494 $>\mathrm{t}$-table) on marketing performance. So, the mediation is partial. But the relationship between innovation capability and indigenous product attractiveness is statistically insignificant $(0,901<\mathrm{t}$-table). Therefore, the $\mathrm{H} 2$ hypothesis is not accepted. The result of mediation analysis is presented in table 2 as follows.

Table 3. Result of Mediation Analysis

\begin{tabular}{|c|c|c|}
\hline Relationship & p-value & Effect \\
\hline $\begin{array}{l}\text { Market sensing capability } \rightarrow \text { Indigenous product } \\
\text { attractiveness } \rightarrow \text { marketing performance }\end{array}$ & 0.266 & Not mediated \\
\hline $\begin{array}{l}\text { Innovation capability } \rightarrow \text { Indigenous } \\
\text { attractiveness } \rightarrow \text { marketing performance }\end{array}$ & 0.010 & Full mediating \\
\hline
\end{tabular}

\section{CONCLUSION}

In this study, we focused on the role of market sensing capability and innovation capability in fostering marketing performance by exploring the mediating effect of indigenous product attractiveness. Consistent with our expectations that market sensing capability has a positive and significant influence on indigenous product attractiveness. In addition, it is also known that and indigenous product attractiveness has a positive and significant influence on marketing performance.

Another significant contribution of this study is to provide empirical evidence that indigenous product attractiveness mediates the relationship between market sensing capability and marketing performance. Analysis of market opportunities is very important because companies need to know the number of opportunities available in marketing their products and can determine whether the market is large enough to support other products and still make a profit. The success of the company in achieving its goals and objectives is very important by companies that advance their products, to advance the market in the future that is needed. Analyzing market opportunities is also to make a decision whether the company will continue to increase its activities by increasing its productivity or having to leave the market.

Market opportunity analysis is a research process of external environmental factors that affect the company's business activities. The external environment is an uncontrollable force, so companies must adapt, and also produce challenges and opportunities. Companies must be careful in analyzing their environment in order to 
avoid challenges and take advantage of opportunities. To increase sales volume and compete for a large market, the company must use appropriate policies to obtain market opportunities that exist. Next the company must see the potential of the market.

Companies that care deeply about their markets will learn about consumers, competitors and distribution channels. Because they have a better ability than their competitors in the trends, both current and future. In the batik business, entrepreneurs must be able to analyze the market, so they can create batik that has an indigenous appeal and is expected to improve performance. But, indigenous product attractiveness not mediates the relationship between market sensing capability and marketing performance.

Innovation is usually associated with developing something new and has the potential to attract consumers in the market. Contrary to prediction and different from previous research (Ferdinand \& Fitriani, 2015) the relationship between innovation capability and indigenous product attractiveness is statistically insignificant. Attractive products resulting from innovation require large costs and also a long time.

Such as batik products, where when the demand for batik products goes up a long time in the manufacturing process requires innovation so that it is fast in the manufacturing process, namely with batik stamp. But the printed batik needs a stamp that is not cheap and reduces indigenous appeal. Surprisingly, indigenous product attractiveness fully mediates the relationship between innovation capability and marketing performance. It means innovation capability could increase marketing performance, only if the Batik SMEs could make the indigenous and attractive product. Products with cultural values or in this case referred to as indigenous are seen as unique products that have the potential to attract consumers.

\section{Implications}

This research provides several academic and practical contributions. First, by using indigenous product attractiveness as a mediating variable, it gives a novelty for further research. Second, this study also provides guidelines for practitioners, especially in small businesses. This study concludes that market sensing capability innovation capability can increase marketing performance. Moreover, indigenous product attractiveness as a mediating variable provides a fresh finding and it made a significant contribution to the research. To make attractive products, entrepreneurs must have high market sensing capabilities. So that marketing performance will increase, through an increase in profits. And the owner must increase the innovation capability level to increase marketing performance through indigenous product attractiveness.

\section{Limitations and Suggestions for Future Research}

This study contains several limitations and can be further developed in the future. We discuss limitations and some possible new contributions to future research. First, one of the limitations of the cross-section method is that it cannot prove a causal relationship. Therefore, a longitudinal design is needed. Second, We limited the respondent only owner of Batik SMEs, further research must be expand to more general SMEs and use large size sample with the owner of handicraft as respondents.

\section{REFERENCES}

Acquaah, M. \& Agyapong, A. (2015). The Relationship between Competitive Strategy and Firm Performance in Micro and Small Businesses in Ghana: The Moderating Role of Managerial and Marketing Capabilities. Africa Journal of Management, 1(2), pp. 172-193. doi: 10.1080/23322373.2015.1025684.

Adler, P. \& Shenbar, a (1990). Adapting your technological base: the organizational challenge. Sloan Management Review, 32(1), pp. 25-37. doi: 10.1080/14783363.2013.791102. 
Ahmed, A. M., Ibrahim, S.B. \& Hasaballah, A. H. A. (2017). Market sensing, innovation capability and market performance: The moderating role of internal information dissemination. International Journal of Advanced and Applied Sciences, 4(8), 56-67. https://doi.org/10.21833/ijaas.2017.08.009.

Akgün, A. E., Keskin, H. \& Byrne, J. C. (2014). Complex adaptive systems theory and firm product innovativeness. Journal of Engineering and Technology Management - JET-M, 31(1), 21-42. https://doi.org/10.1016/j.jengtecman.2013.09.003.

Angelis, M. De, Carpenter, G.S., Angelis, M. De \& Shavitt, S. (2009a). The Effect of Adding Features on Product Attractiveness : The Role of Product Perceived. 36, 651-652.

Ardyan, E. (2016). Market Sensing Capability and SMEs Performance: The Mediating Role of Product Innovativeness Success. (January).

Avlonitis, G.J. \& Salavou, H.E. (2007). Entrepreneurial orientation of SMEs, product innovativeness, and performance. Journal of Business Research, 60(5), 566-575.

Ayob, A.H. \& Hussain, W.M.H.W. (2016). Buying local or imported goods? Profiling non-income consumers in developing countries. International Review of Management and Marketing, 6(4), 688-695.

Baczyńska, E., Lorenc, M.W. \& Kaźmierczak, U. (2018). The Landscape Attractiveness of Abandoned Quarries, Geoheritage, 10(2), pp. 271-285. doi: 10.1007/s12371-017-0231-6.

Baker, W. E. \& Sinkula, J.M. (2005). Environmental Marketing Strategy and Firm Performance: Effects on New Product Performance and Market Share. Journal of the Academy of Marketing Science, 33(4), 461-475. https://doi.org/10.1177/0092070305276119.

Banerjee, S.B. (2002). Corporate environmentalism: The construct and its measurement. Journal of Business Research, 55(3), 177-191.

Bharadwaj, S.G., Varadarajan, P.R. \& Fahy, J. (1993). Sustainable competitive advantage in service industries: a conceptual model and research propositions. Journal of marketing, 57(4), 83-99.

Bouguerra, A., Mellahi, K., Glaister, K., Hughes, M. \& Tatoglu, E. (2020). Revisiting the concept of absorptive capacity: The moderating effects of market sensing and responsiveness.

Brislin, R.W. (1970). Back-translation for cross-cultural research. Journal of cross-cultural psychology, 1(3),

Chambers, S., Lobb, A., Butler, L., Harvey, K. \& Bruce Traill, W. (2007). Local, national and imported foods: A qualitative study. Appetite, 49(1), 208-213. https://doi.org/10.1016/j.appet.2007.02.003.

Chen, C.Y., Huang, H.H. \& Wey, S.C. (2017). The mediating roles of differentiation strategy and learning orientation in the relationship between entrepreneurial orientation and firm performance. Corporate Management Review, 37(1), 1-40.

Coviello, N.E., Brodie, R.J. \& Munro, H.J. (2000). An investigation of marketing practice by firm size. Journal of Business Venturing, 15(5), 523-545. https://doi.org/10.1016/So883-9026(98)ooo35-4.

Dai, L., Maksimov, V., Gilbert, B.A. \& Fernhaber, S.A. (2014). Entrepreneurial orientation and international scope: The differential roles of innovativeness, proactiveness, and risk-taking. Journal of Business Venturing, 29(4), 511-524. https://doi.org/10.1016/j.jbusvent.2013.07.004.

Day, G. S. (1994). The capabilities of market-driven organizations. Journal of marketing, 58(4), 37-52.

Day, G.S. (2002). Managing the market learning process. Journal of Business \& Industrial Marketing, 17(4), 240-252.

Dormer, P. (1997). The culture of craft. Manchester University Press (Ed.).

Dyah, P. \& Korry, P. (2017). Increase the Attractiveness of Local Fruits to Buying Intention of Hedonic Consumers in Bali. 4(6), 10-16.

Ferdinand, A.T. \& Fitriani, L.K. (2015). Acculturative Iconic Product Attractiveness And Marketing Performance. 15-23. https://doi.org/10.20460/JGSM.2015915570.

Foley, A. (2004). Towards a further understanding of the development of market orientation in the firm : a conceptual framework based on the market-sensing capability. 230(December), 219-231. https://doi.org/10.1080/0965254042000308048.

Fuchs, C., Schreier, M. \& Osselaer, S.M.J.Van. (2015). The Handmade Effect : What's Love Got to Do with It? 2429(Barber 2013). https://doi.org/10.1509/jm.14.0018.

Gloet, M. \& Samson, D. (2016). Knowledge management and systematic innovation capability, International Journal of Knowledge Management, 12(2), pp. 54-72. doi: 10.4018/IJKM.2016040104.

Huber, G.P. (1991). Organizational learning: The contributing processes and the literatures. Organization science, 2(1), 88-115.

Hughes, M., Martin, S.L., Morgan, R.E. \& Robson, M.J. (2010). Realizing Product-Market Advantage in HighTechnology International New Ventures: The Mediating Role of Ambidextrous Innovation. Journal of International Marketing, 18(4), 1-21. https://doi.org/10.1509/jimk.18.4.1.

Huhtala, J.P., Sihvonen, A., Frösén, J., Jaakkola, M. \& Tikkanen, H. (2014). Market orientation, innovation capability and business performance. Baltic Journal of Management. 9(2), pp. 134-152. doi: 10.1108/BJM-03-2013-0044.

Ilieş, A., Ilieş, D. C., Josan, I., Wendt, J., Herman, G. V., \& Grama, V. (2010). The identification, evaluation, 
quantification and capitalization trough tourism of the authentic resources from Crisana-Maramures with the purpose of elaborating a strategy of cross-border integrated sustainable development. Methodological approach. Analele Universitatii din Oradea, Seria Geografie, 20(1), 127-140.

Kartajaya, H. (2004). Positioning, diferensiasi dan brand. Gramedia Pustaka Utama.

Kim, G., Duffy, L.N. \& Moore, D.W. (2020). Tourist attractiveness: measuring residents' perception of tourists, Journal of Sustainable Tourism. Routledge, 28(6), pp. 898-916. doi: 10.1080/o9669582.2019.1708919.

Laforet, S. (2011). A framework of organizational innovation and outcomes in SMEs. International Journal of Entrepreneurial Behavior \& Research, 17(4), 380-408.

Lawson, B. \& Samson, D. (2001). Developing Innovation Capability In Organisations: A Dynamic, 5(3), pp. $377-400$.

Lindblom, A.T., Olkkonen, R.M., Mitronen, L. \& Kajalo, S. (2008). Market-Sensing Capability and Business Performance of Retail Entrepreneurs. 4(3), 219-236.

Lumpkin, G.T. \& Dess, G.G. (1996). Clarifying the entrepreneurial orientation construct and linking it to performance. Academy of Management Review, 21(1), 135-172.

Miller, D. \& Friesen, P.H. (1983). Strategy-making and environment: the third link. Strategic management journal, 4(3), 221-235.

Olson, E.M., Slater, S.F. \& Hult, G.T.M. (2005). The performance implications of fit among business strategy, marketing organization structure, and strategic behavior. Journal of Marketing, 69(3), 49-65. https://doi.org/10.1509/jmkg.69.3.49.66362.

Pono, M., Munir, A.R., Maming, J. \& Kadir, N. (2019). Mediation effect of acculturative aesthetic attractiveness on the relation of product innovation to increase SMEs marketing performance. IOP Conference Series: Earth and Environmental Science, 235(1). https://doi.org/10.1088/1755-1315/235/1/012065.

Presenza, A., Messeni Petruzzelli, A. \& Sheehan, L. (2019). Innovation trough tradition in hospitality. The Italian case of Albergo Diffuso, Tourism Management. Elsevier, 72(January 2018), pp. 192-201. doi: 10.1016/j.tourman.2018.11.020.

Schnurr, B., Brunner-sperdin, A. \& Stokburger-sauer, N.E. (2017). The effect of context attractiveness on product attractiveness and product quality: the moderating role of product familiarity. 241-253. https://doi.org/10.1007/s11002-016-9404-3.

Setyawati, H.A. (2018). Daya tarik produk indigeounous untuk meningkatkan kinerja pemasaran. 7, 1-4.

Shaari, N. (2015). Indigenous Knowledge Creativity in Batik Cultural Product based on Kansei', pp. 56-6o.

Sigala, M. (2018). New technologies in tourism: From multi-disciplinary to anti-disciplinary advances and trajectories. Tourism Management Perspectives, 25(December), 151-155. https://doi.org/10.1016/j. tmp.2017.12.003.

Sims, R. (2009). Food, place and authenticity: Local food and the sustainable tourism experience. Journal of Sustainable Tourism, 17(3), 321-336. https://doi.org/10.1080/o9669580802359293.

Slater, S.F., Hult, G.T.M. \& Olson, E.M. (2010). Factors influencing the relative importance of marketing strategy creativity and marketing strategy implementation effectiveness, Industrial Marketing Management. Elsevier Inc., 39(4), pp. 551-559. doi: 10.1016/j.indmarman.2008.03.007.

Slater, S.F., Mohr, J.J. \& Sengupta, S. (2013). Radical Product Innovation Capability: Literature Review , Synthesis, and Illustrative Research Propositions. 31(3). https://doi.org/10.1111/jpim.12113.

Solomon, K.D., Stewart, W.C., Hunt, H.H. \& Cate, E.A. (1997, March). Intracameral carbachol 0.o1\% in phacoemulsification and posterior chamber lens implantation. In Investigative Ophthalmology \& Visual Science (Vol. 38, No. 4, pp. 1297-1297). 227 East Washington SQ, Philadelphia, PA 19106: Lippincott-Raven PUBL.

Song, X.M. \& Parry, M.E. (1997). A cross-national comparative study of new product development processes: Japan and the United States. Journal of marketing, 61(2), 1-18.

Tang, Z. \& Tang, J. (2012). Entrepreneurial orientation and SME performance in China's changing environment: The moderating effects of strategies. Asia Pacific Journal of Management, 29(2), 409-431. https://doi.org/10.1007/s10490-010-9200-1185-216.

Verreynne, M.L. et al. (2019). Innovation diversity and uncertainty in small and medium sized tourism firms', Tourism Management. Elsevier, 72(April 2018), pp. 257-269. doi: 0.1016/j.tourman.2018.11.019.

Vorhies, D.W. \& Morgan, N.A. (2005). Benchmarking marketing capabilities for sustainable competitive advantage. Journal of marketing, 69(1), 80-94.

Wardani, W.N.R. \& Widodo (2020). Antecendent and consequence destination innovation, Geojournal of Tourism and Geosites, 28(1), pp. 9-20. doi: 10.30892/gtg.28101-448.

*** Dagooc (2010). https://www.philstar.com/cebu-business/2010/o4/22/568354/souvenir-retailers-urgedadopt-uniform-pricing.

www.hoovers.com.

Submitted:

21.02.2020
Revised:

05.05.2020
Accepted and published online 15.05.2020 